\title{
Design and fabrication of polycaprolactone/gelatin composite scaffolds for diaphragmatic muscle reconstruction
}

\author{
Tina Navaei ${ }^{1,2}$, Peiman Brouki Milan ${ }^{1,2}$, Ali Samadikuchaksaraei ${ }^{1,2}$, Hamid Reza Davari ${ }^{3}$, John G. \\ Hardy ${ }^{4,5}$, Masoud Mozafari ${ }^{1,2, *}$ \\ ${ }^{1}$ Cellular and Molecular Research Center (CMRC), Iran University of Medical Sciences (IUMS), \\ Tehran, Iran \\ ${ }^{2}$ Department of Tissue Engineering \& Regenerative Medicine, Iran University of Medical \\ Sciences (IUMS), Tehran, Iran \\ ${ }^{3}$ Department of Surgery, Tehran University of Medical Sciences, Tehran, Iran \\ ${ }^{4}$ Department of Chemistry, Lancaster University, Lancaster, UK \\ ${ }^{5}$ Materials Science Institute, Lancaster University, Lancaster, UK \\ * Corresponding author: M. Mozafari, PhD
}

Currently at: Lunenfeld-Tanenbaum Research Institute, Mount Sinai Hospital, University of Toronto, Toronto, ON, Canada; Email: mozafari.masoud@gmail.com 


\section{Abstract}

Diaphragmatic wall defects caused by congenital disorders or disease remain a major challenge for physicians worldwide. Polymeric patches have been extensively explored within research laboratories and the clinic for soft tissue and diaphragm reconstruction. However, patch usage may be associated with allergic reaction, infection, granulation, and recurrence of the hernia. In this study, we designed and fabricated a porous scaffold using a combination of 3D printing and freeze-drying techniques. A 3D printed polycaprolactone (PCL) mesh was used to reinforcegelatin scaffolds, representing an advantage over previously reported examples since it provides mechanical strength and flexibility. In vitro studies showed that adherent cells were anchorage-dependent and grew as a monolayer attached to the scaffolds. Microscopic observations indicated better cell attachments for the scaffolds with higher gelatin content as compared with the PCL control samples. Tensile testing demonstrated the mechanical strength of samples was significantly greater than adult diaphragm tissue. The biocompatibility of the specimens was investigated in vivo using a subcutaneous implantation method in BALB/C adult mice for 20 days, with the results indicating superior cellular behavior and attachment on scaffolds containing gelatin in comparison to pure PCL scaffolds, suggesting that the porous PCL/gelatin scaffolds have potential as biodegradable and flexible constructs for diaphragm reconstruction.

Keywords: Diaphragm; Regeneration; Biomaterials; Scaffold; Cellular response; Tissue engineering 


\section{Introduction}

Abnormal developments of the diaphragm that present a physical barrier between thoracic and abdominal cavities may cause serious problems for infants (McLaughlin et al., 2019). For instance, congenital diaphragmatic hernia $(\mathrm{CDH})$ is a problem that happens 1 in 2500 births (Campiglio et al., 2019) and instant surgical treatment is required for large defects. A hernia can be repaired surgically depending on the type of defect: the hole can be simply sewn shut if it is small enough (in such cases, the operations are called primary repairs (Magrina et al., 2019)); alternatively, if a significant portion of the diaphragm is absent or the hole is too large, it needs to be repaired with additional material or tissue. Ideal materials/tissues for diaphragm repair should be safe, have sufficient mechanical strength, present minimal risk of hernia recurrence, have potential to grow with the infant and not affect chest wall development or produce deformity, and support both stromal and migratory cells and augment their function in regenerating new tissue (Smith et al., 2004).

Patch repair is a method using a synthetic biomaterial to close the opening (University of California San Francisco, 2018, Suzuki et al., 2018, Hancox et al., 2019, Navaei et al., 2019). Some of the most often used synthetic materials used in patches for diaphragm treatment are expanded polytetrafluoroethylene (ePTFE) patches (Grethel et al., 2006, Omura et al., 2020), reinforced silastic sheets (Smith et al., 2004), and polypropylene meshes (Mohsina et al., 2017). However, using synthetic materials may cause an allergic reaction, granulation tissue formation, infection or mechanical insufficiencies with native tissue thoracic deformity and recurrence of the hernia (Zhao et al., 2013, Kuevda et al., 2019, Kaarthick et al., 2017). In addition, synthetic patches do not grow as the child grows (Lantis li et al., 2000, Fauza et al., 2001); hence, patients need to undergo 
numerous surgeries as they mature. To overcome the problems associated with synthetic patches, autologous tissues were introduced to repair large diaphragmatic defects (Rathore et al., 2019, Rathore et al., 2018). Typically, surgeons use latissimus dorsi and external abdominal oblique muscle flaps to cover the hole in the diaphragm which is called a flap repair. In select circumstances, infants may be a candidate for a minimally invasive thoracoscopic repair (University of California San Francisco, 2018). Autologous grafting is considered a low-risk procedure with minimal discomfort for patients, however, the surgical process is quite challenging; lengthy operations, which may lead to infection or bleeding, and abdominal wall weakness are the two main disadvantages of this technique (Masumoto et al., 2007, Zhao et al., 2013).

Tissue engineering approaches represent an alternative strategy for diaphragmatic hernia repair since the host cells will proliferate through the biodegradable tissue scaffold, resulting in regenerated tissue which is biologically similar to the native tissue. The successful repair of diaphragms has been achieved using amniocyte based engineered tendons (Fuchs et al., 2004), VEGF-loaded porous silica gel and acellular diaphragmatic matrix (ADM) with myoblasts cultured on their surface into a diaphragmatic hernia (Conconi et al., 2009), and a variety of other scaffolds (Brouwer et al., 2014, Brouwer et al., 2013a, Zhao et al., 2013, Urita et al., 2008, Brouwer et al., 2013b). Collagen-based constructs reinforced with Vicryl ${ }^{\circledR}$ were shown to result in diaphragm eventration in lambs, where the eventration may be avoided by using materials with slower degradation rates (Brouwer et al., 2014), and heparinized collagen scaffolds implanted in a rat model were shown to enhance ingrowth of blood vessels without evidence of eventration nor herniation (Brouwer et al., 2013b). 
The properties required for scaffolds for diaphragmatic hernia repair include flexibility, strength and degradability, and composites of natural polymers (e.g. gelatin) and synthetic polymers (e.g. FDA-approved PCL (Munir and Callanan, 2018)) could potentially form the basis of functional scaffolds for diaphragm repair (Navaei et al., 2019, Zhao et al., 2013, Hancox et al., 2019). Both gelatin and PCL are biodegradable and their combination compensates for the limitations of each other to some extent. Here, we report our efforts in the design and fabrication of porous $\mathrm{PCL} /$ gelatin composite scaffolds reinforced with a layer of 3D-printed PCL mesh, yielding robust, flexible biodegradable scaffolds that avoid the necessity for multiple surgeries after diaphragmatic hernia repair.

\section{Materials and Methods}

\subsection{Scaffold Fabrication and Characterization}

The composite scaffold from a blend of PCL (average $80,000 \mathrm{Mn}, 1.145 \mathrm{~g} / \mathrm{mL}$ density at 25 ${ }^{\circ} \mathrm{C}$, Sigma-Aldrich) and gelatin type A (approx. 175 Bloom, Sigma-Aldrich) from porcine skin was fabricated by a combination of freeze-drying and 3D-printing. First, a $1 \times 45 \times 45 \mathrm{~mm}$ PCL mesh was designed and 3D printed (FDM 3D printer, Jinhua Feiren Technology Co., Ltd, CN) to act as reinforcement for the scaffold. The PCL filament (1.75 $\mathrm{mm}$ in diameter) was extruded through a $220^{\circ} \mathrm{C}$ nozzle with $400 \mu \mathrm{m}$ diameter and head speed of $8 \mathrm{~mm} / \mathrm{s}$ to print scaffolds layer by layer onto a heated bed (approximately $60^{\circ} \mathrm{C}$ ). Second, 5 different concentrations of $\mathrm{PCL}$ and gelatin blend were prepared using acetic acid $99.9 \%(0.5 \mathrm{~g} / \mathrm{mL})$ as shown in Table 1.

(Table 1) 
The prepared solutions were poured into five aluminum $4.5 \times 4.5 \mathrm{~mm}$ molds and five PCL

meshes were placed in each one. Then they were frozen at $-80{ }^{\circ} \mathrm{C}$ for 24 hours and subsequently placed for 4 hours in a freeze-dryer $\left(-40{ }^{\circ} \mathrm{C}\right.$, Edwards Vacuum) to remove all volatiles. The schematic of the fabrication process and treatment strategy is shown in Fig. 1.

(Figure 1)

\subsection{Cell Culture and Imaging}

The scaffolds were sterilized with 70\% alcohol at room temperature for $2 \mathrm{~h}$ and incubated at $37^{\circ} \mathrm{C}$ for 30 min in culture medium (DMEM high Glucose, Gibco) supplemented with Fetal bovine serum (FBS, Gibco) prior to cell seeding. Fibroblast cells (3T3 cell line) were thawed in a $37^{\circ} \mathrm{C}$ water bath and then transferred to the prepared scaffolds in a T25 cell culture plate (SPL company) containing $5 \mathrm{~mL}$ of growth media. The plate was incubated at $37^{\circ} \mathrm{C}$ overnight and cell attachments were observed under a microscope.

Samples with diameters of $0.5 \mathrm{~cm}$ were seeded with 10000 cells and then imaged using scanning electron microscopy (SEM) to view the surface and cross section following overnight fixation with 2.5 M glutaraldehyde (Sigma Aldrich) and dehydration with ethanol. Finally, scaffolds were sputter-coated with an ultrathin layer of gold in an Edwards Scancoat Six Pirani 501 coating system (Edwards High Vacuum International, Crawley, UK) and imaged at $20 \mathrm{kV}$ at magnifications ranging from $30 x$ to $1300 x$. For cross section imaging, the scaffolds were frozen with liquid nitrogen, fractured, and then gold coated with a sputter coater. 


\subsection{Biocompatibility Assay}

In vivo biocompatibility was investigated by implanting scaffolds subcutaneously in five groups of BALB/c adult mice weighing 100-120 g. Animals were anesthetized using $\mathrm{CO}_{2}$ inhalation system. The back was shaved, disinfected with $2 \%$ iodine solution, and sterilely wrapped. The incisions were closed with Polysorb 4.0 or closed with clips. All animals were observed daily for signs of wound infection, redness or illness. After 20 days they were sacrificed and the scaffolds were removed with the surrounding tissue. Subsequently, the scaffolds were photographed and prepared for further examinations.

Additionally, a resazurin assay was used to evaluate the biocompatibility of prepared scaffolds. Resazurin assay kit (cell viability) ab129732 is a fluorometric/colorimetric assay that allows the determination of the metabolic capacity of live cells in a high throughput format. After culturing fibroblast cells (5000 cells in each well) in sterile cell culture plates (96 well), the manufacturer's protocol was followed: resazurin reagent was added to cells in growth media and incubated for $4 \mathrm{hr}$ at $37^{\circ} \mathrm{C}$ and finally analyzed with a microplate reader.

All harvested scaffolds were fixed in $10 \%$ natural buffer formalin solution (NBF, Sigma Aldrich) for 4 days at $25^{\circ} \mathrm{C}$ and then excessive formalin was rinsed with water for $1 \mathrm{~h}$. Ethanol solution was used to dehydrate samples at room temperature. Subsequently, scaffolds were embedded in liquid Paraffin wax (Merck, Germany) and left to harden. Using a microtome (Leica RM 2065) blocks were cut in $7 \mu m$ thick sections and then stained with Hematoxylin and Eosin (H\&E, Sigma Aldrich). Samples were then evaluated by light microscopy. 
The animal procedures were performed at Iran University of Medical Science according to the Institutional Animal Care and Use Committee (IACUC) guidelines and the policy on Human Care and Use of Laboratory Animals and Guide for the Care and Use of Laboratory Animals (Ethical approval number; IR.IUMS.REC.1398.055, Date: 20/01/2019).

\subsection{Biodegradation Rate Evaluation}

PBS is a buffer commonly used in biological applications and it closely mimics the osmolarity, $\mathrm{pH}$, and ion concentrations of the human body. According to the protocol, for preparation of $1 \mathrm{LPBS}, 8 \mathrm{~g}$ of $\mathrm{NaCl}, 200 \mathrm{mg}$ of $\mathrm{KCl}, 1.44 \mathrm{~g}$ of $\mathrm{Na}_{2} \mathrm{HPO}_{4}$, and $240 \mathrm{mg}$ of $\mathrm{KH}_{2} \mathrm{PO}_{4}$ should be added to $800 \mathrm{~mL}$ of distilled water and adjust to approximately $\mathrm{pH} 7.4$, then distilled water was added until the volume was $1 \mathrm{~L}$ (Protocols Online, 2016).

In order to calculate the degradation rate of scaffolds, samples $(1 \times 1 \mathrm{~cm})$ were weighed and immersed in falcon tubes filled with $10 \mathrm{~mL}$ of PBS. The specimens were recovered each week after 8 weeks, dried in an oven at $40{ }^{\circ} \mathrm{C}$, and then weighed to assess their degradation. Precentage weight loss $\left(W_{L} \%\right)$ was calculated using equation 1 ( $W_{L}$ : weight loss, $W_{0}$ : original weight, $W_{D}$ : the weight of dried sample).

Eq. 1

$$
w_{L} \%=\frac{w_{0}-w_{D}}{w_{0}} \times 100
$$

\subsection{Water Contact-Angle Measurement}

The wettability of samples was measured according to ASTM D7334 standard method. The surface tension between scaffolds and a drop of distilled water $(4 \mu \mathrm{L})$ were compared and using 
Young's equation (Eq. 2) the contact angle between the water drop and scaffold was evaluated $\left(\theta\right.$ : contact angle, $\sigma_{\mathrm{lg}}$ : the surface tension of the liquid, $\sigma_{\mathrm{sl}}$ : the interfacial tension between liquid and solid, $\sigma_{\mathrm{sg}}$ : the surface free energy of the solid), in accordance with Stalder (Stalder et al., 2010, Stalder et al., 2006).

Eq. 2

$\sigma_{\mathrm{sg}}=\sigma_{\mathrm{s} \mid}+\sigma_{\mid \mathrm{g}} \cdot \cos \theta$

\subsection{Fourier Transformation Infrared (FTIR) Spectroscopy}

FTIR spectra of dried gelatin/PCL composite were obtained using an FTIR spectrometer (PerkinElmer 2000). Dried scaffolds and pure starting materials were ground and mixed thoroughly with potassium bromide at a ratio of 1:5 (sample: $\mathrm{KBr}$ ). The transparent $\mathrm{KBr}$ discs were prepared by compressing the powders under a force of $2.8-3 \mathrm{MPa}$ for 3-5 min in a hydraulic press. The IR spectra of the pellets were then analyzed. Fifty scans were obtained at a resolution of $10 \mathrm{~cm}^{-1}$ between 4000 and $400 \mathrm{~cm}^{-1}$ wavenumbers

\subsection{Tensile Test}

The mechanical properties of scaffolds were assessed at designated time points with uniaxial load testing equipment (Model \#5566, Instron Corporation, Issaquah, WA). Scaffolds were cut into $1 \times 4 \mathrm{~cm}$ samples and subjected to controlled tension until failure. At least three samples were tested for each type of scaffold (Lu et al., 2014).

\subsection{Determination of Cellular Viability with MTT Assay}


The viability of fibroblasts (3T3 cells) was determined by 3-[4, 5-Dimethylthiazol-2-yl]-2, 5 Diphenyltetrazolium Bromide (MTT) assay. This assay shows the transformation of light yellow MTT into dark blue Formazan as a result of mitochondrial dehydrogenase activity. The intensity of the sample color was then determined using a spectrophotometer.

Each scaffold was seeded with 5000 cells and maintained at $37^{\circ} \mathrm{C}$ under $5 \% \mathrm{CO}_{2}$. A various time points the culture medium in the samples was removed and rinsed three times with PBS.

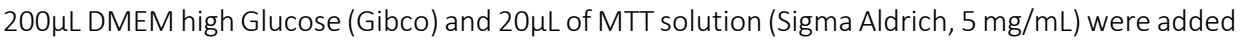
to each well and then incubated at $37^{\circ} \mathrm{C}$ and $5 \% \mathrm{CO}_{2}$ for $4 \mathrm{~h}$. After removing the upper medium, $100 \mu \mathrm{L}$ of DMSO (Merck, Germany) was added to each well to solubilize the intracellular Formazan and then incubated at $37^{\circ} \mathrm{C}$ and $5 \% \mathrm{CO}_{2}$ for $10 \mathrm{~min}$. The absorbance of the produced Formazan was measured at $570 \mathrm{~nm}$. The experiment was repeated three times, the results of which are presented as means (Mansourizadeh et al., 2013).

\subsection{In vivo biocompatibility assay}

Tissue sections were prepared for immunofluorescent staining in order to assess the infiltration of macrophages in the site of implantation. Slides were treated with citrate buffer for antigen retrieval (Dako North America Inc. Carpinteria) and then placed in a microwave device for $20 \mathrm{~min}\left(>100^{\circ} \mathrm{C}\right)$, followed by resting for $30 \mathrm{~min}$ to cool down. Next, 10\% goat serum (Sigma Aldrich) was added to each section for 1 hour at $22-25^{\circ} \mathrm{C}$. Then, slides were treated with the primary antibody (F4/80 1:1500 dilution, eBioscience) and incubated at $4^{\circ} \mathrm{C}$ overnight. After washing with Tris Buffered Saline (TBS, Sigma Aldrich), the slides were incubated with Goat AntiRat IgG H\&L (Alexa Fluor ${ }^{\circledR}$ 488) (ab150157) as a secondary antibody or $30 \mathrm{~min}$ at room 
temperature. The tissue sections were rinsed in running tap water for $20 \mathrm{~min}$. After dehydration, labeled cells were visualized by the use of a Lionheart FX-Automated Microscope, BioTek.

\section{Results and discussion}

\subsection{Scaffold Characterization}

The morphology and porosity of scaffolds were studied using SEM microscopy. SEM images indicated a high porosity at cross sections, and slightly more closed pores on surface sides (Fig. 2). As shown in the images, cell attachment was observed for samples containing gelatin as gelatin is known to promote cell adhesion, cell migration (Ammann et al., 2015) and proliferation on gelatin treated scaffolds (Ma et al., 2005). The scaffold pores ranged in size from $1 \mu \mathrm{m}$ to $100 \mu \mathrm{m}$ and were suitable for cell proliferation since the diameter of skeletal muscle cells, the major components of the diaphragm, are approximately of the same size (10 to $100 \mu \mathrm{m}$ ) (Australia, 2009, Merrell and Kardon, 2013).

(Figure 2)

\subsection{Water Contact-Angle Measurement}

Wettability measurement of samples showed them to be highly hydrophilic. The sample with the highest gelatin content $(\mathrm{PCL} / 4 \mathrm{G})$ showed the lowest contact angle (i.e. most wettability) demonstrating that the presence of gelatin improved the hydrophilicity of the scaffolds due to the hydrophilic moieties (e.g. amine and carboxylic groups) displayed on gelatin (Kharaziha et al., 2013). The interconnected pore structure of the scaffolds, may in some cases, cause the water 
drop to absorb instantly making it impossible to take a picture for contact angle measurement; accordingly, a video was taken from the point of water drop contact until full absorption, and the contact angles were determined at specific times in each video for comparative purposes (see Fig.

3).

(Figure 3)

\subsection{Mechanical Properties}

The mechanical strength of the samples increased considerably due to the use of a PCL mesh as reinforcement. The minimum UTS of thescaffolds was measured to be between $2.7 \mathrm{MPa}$ and $4 \mathrm{MPa}$, with pure PCL having the maximum UTS (see Fig. 4).

(Figure 4)

\subsection{Fourier Transformation Infrared (FTIR) Spectroscopy}

FTIR spectroscopy of the scaffolds is reported in Figure 5. The peaks at $2866-2947 \mathrm{~cm}^{-1}$ (CH), $1730 \mathrm{~cm}^{-1}$ (C=O ester), $1469 \mathrm{~cm}^{-1}, 1366 \mathrm{~cm}^{-1}, 1249 \mathrm{~cm}^{-1}$, and $1240 \mathrm{~cm}^{-1}$ are characteristic of PCL. The peaks observed in the spectral range $3200-3400 \mathrm{~cm}^{-1}, 1650 \mathrm{~cm}^{-1}, 1534 \mathrm{~cm}^{-1}$ and $1420 \mathrm{~cm}^{-}$

${ }^{1}$, respectively, indicate the presence of $\mathrm{N}-\mathrm{H}$ functional groups, $\mathrm{C}=\mathrm{O}$ amide, $\mathrm{N}-\mathrm{H}$ and $\mathrm{C}-\mathrm{N}$, which are characteristic of gelatin (Kharaziha et al., 2013).

(Figure 5) 


\subsection{Degradation Test}

Observation of weight loss over 8 weeks showed samples with the highest gelatin content sample $(\mathrm{PCL} / 4 \mathrm{G})$ had the highest weight loss \% (5.6\%), with other samples with higher PCL contents showing concomitantly lower percentage weight loss over the same period (see Fig. 6).

(Figure 6)

\subsection{Determination of Cellular Viability}

The cell viability of samples was determined after 3 days in culture. Cell viability decreased between 1 to 3 days in all cases except for the control sample and PCL/1G, however, the decrease was not statistically significant for any group and is likely the result of the relatively high seeding density. The cells were observed to adhere to and proliferate on the subsrates as confirmed by a standard live/dead assay (Resazurin assay, Fig. 7B) and confocal microscopy images (Fig. 7C) over the period of 1 week.

(Figure 7)

\subsection{Biocompatibility Assay}

Macroscopic images of implanted scaffolds in mice and histologic images of the surrounding fibrotic tissue of each group are shown in Fig. 8. It can be observed that minimal fibrotic tissue is formed around the implanted group 5 samples at 20 days post-implantation (Table 
2), demonstrating that samples containing $60 \% \mathrm{PCL}$ and $40 \%$ gelatin were the most biocompatible of all of the samples studied (Ratner, 2015, Tang and Hu, 2005). The surface chemistry of implanted materials is very important for the recruitment of immune cells and foreign body reaction. The hydrophobicity of materials tends to enhance non-specific protein adsorption and increase immune cell recruitment, whereas hydrophilic materials and hydrogels limit non-specific protein adsorption due to the high amount of water on the surface of this materials (GonzalezSimon and Eniola-Adefeso, 2012, Hezi-Yamit et al., 2009, Jones et al., 2007) - however, these are generalizations, and adsorption of specific species needs to be studied on a sample by sample basis. Minimal fibrosis capsule formation was observed around the samples containing $40 \%$ gelatin which may be due to their small pore size compared to other samples (which has been observed to diminish fibrosis in vivo in other studies (Cao et al., 2010)).

(Figure 8)

(Table 2)

The presence of adipose tissue is related to the same immune system response, although it is important to note that the mechanisms that link adipose tissue formation and the immune response are not fully understood [3]. But the previous investigation showed that non-reactive and biocompatible materials tend to be encapsulated by adipose tissue, while incompatible materials did not present this phenomenon (Villarreal-Gómez et al., 2014). An in vivo cytocompatibility assay for evaluating inflammatory response to subcutaneously-implanted scaffolds using F4/80 as a marker, showed cells of positive activated macrophages staining in the 
implanted site, and scaffolds containing $40 \%$ gelatin showed a significantly decreased number of cells compared to the other groups.

\section{Conclusion}

The present study describes five tissue scaffolds made of PCL and different concentrations of gelatin, the properties of which could be tailored using a combination of 3D printing and freezedrying. Porous composite scaffolds made of $\mathrm{PCL} /$ gelatin had usable mechanical properties along with cytocompatibility and biodegradability, which can support cell ingrowth. The printed $\mathrm{PCL}$ mesh within each gelatin scaffold successfully enhanced the mechanical properties of the construct, especially the tensile strength. The hydrophilic scaffolds also provide a suitable environment for cell attachment which can be associated with a minimal foreign body reaction that rapidly resolves. However, further studies are needed to fully determine the function of the scaffolds for reconstructing large diaphragm defects in clinical conditions. 
References:

AMMANN, K. R., DECOOK, K. J., TRAN, P. L., MERKLE, V. M., WONG, P. K. \& SLEPIAN, M. J. 2015. Collective cell migration of smooth muscle and endothelial cells: impact of injury versus non-injury stimuli. Journal of biological engineering, 9, 19.

AUSTRALIA, S. O. A. A. H. B.-T. U. O. W. 2009. Blue Histology - Muscle [Online]. Available: http://www.lab.anhb.uwa.edu.au/mb140/CorePages/Muscle/Muscle.htm [Accessed 2019].

BROUWER, K. M., DAAMEN, W. F., HOOGENKAMP, H. R., GEUTJES, P. J., DE BLAAUW, I., JANSSENKESSELS, W., DE BOODE, W., VERSTEEG, E., WIJNEN, R. M., FEITZ, W. F., WIJNEN, M. \& VAN KUPPEVELT, T. H. 2014. Collagen-Vicryl scaffolds for reconstruction of the diaphragm in a large animal model. Journal of Biomedical Materials Research - Part B Applied Biomaterials, 102, 756-763.

BROUWER, K. M., DAAMEN, W. F., VAN LOCHEM, N., REIJNEN, D., WIJNEN, R. M. H. \& VAN KUPPEVELT, T. H. 2013a. Construction and in vivo evaluation of a dual layered collagenous scaffold with a radial pore structure for repair of the diaphragm. Acta Biomaterialia, 9, $6844-6851$.

BROUWER, K. M., WIJNEN, R. M., REIJNEN, D., HAFMANS, T. G., DAAMEN, W. F. \& VAN KUPPEVELT, T. H. 2013b. Heparinized collagen scaffolds with and without growth factors for the repair of diaphragmatic hernia: construction and in vivo evaluation. Organogenesis, 9, 161-167. 
CAMPIGLIO, C. E., VILLONIO, M., DELLACÀ, R. L., MOSCA, F. \& DRAGHI, L. 2019. An injectable, degradable hydrogel plug for tracheal occlusion in congenital diaphragmatic hernia (CDH). Materials Science and Engineering: C, 99, 430-439.

CAO, H., MCHUGH, K., CHEW, S. Y. \& ANDERSON, J. M. 2010. The topographical effect of electrospun nanofibrous scaffolds on the in vivo and in vitro foreign body reaction. Journal of Biomedical Materials Research Part A: An Official Journal of The Society for Biomaterials, The Japanese Society for Biomaterials, and The Australian Society for Biomaterials and the Korean Society for Biomaterials, 93, 1151-1159.

CONCONI, M. T., BELLINI, S., TEOLI, D., DE COPPI, P., RIBATTI, D., NICO, B., SIMONATO, E., GAMBA, P. G., NUSSDORFER, G. G., MORPURGO, M. \& PARNIGOTTO, P. P. 2009. In vitro and in vivo evaluation of acellular diaphragmatic matrices seeded with muscle precursors cells and coated with VEGF silica gels to repair muscle defect of the diaphragm. Journal of Biomedical Materials Research - Part A, 89, 304-316.

FAUZA, D. O., MARLER, J. J., KOKA, R., FORSE, R. A., MAYER, J. E. \& VACANTI, J. P. 2001. Fetal tissue engineering: diaphragmatic replacement. Journal of pediatric surgery, 36, 146-151.

FUCHS, J. R., KAVIANI, A., OH, J. T., LAVAN, D., UDAGAWA, T., JENNINGS, R. W., WILSON, J. M. \& FAUZA, D. O. 2004. Diaphragmatic reconstruction with autologous tendon engineered from mesenchymal amniocytes. Journal of Pediatric Surgery, 39, 834-838.

GONZALEZ-SIMON, A. L. \& ENIOLA-ADEFESO, O. 2012. Host response to biomaterials. Engineering Biomaterials for Regenerative Medicine. Springer. 
GRETHEL, E. J., CORTES, R. A., WAGNER, A. J., CLIFTON, M. S., LEE, H., FARMER, D. L., HARRISON, M. R., KELLER, R. L. \& NOBUHARA, K. K. 2006. Prosthetic patches for congenital diaphragmatic hernia repair: Surgisis vs Gore-Tex. Journal of Pediatric Surgery, 41, 29-33.

HANCOX, Z., YOUSAF, S., SHAH, T., FHONG, S. C., ZHANG, W., AHMED, N., MOZAFARI, M., NAIR, K., COATES, P. \& SEFAT, F. 2019. Scaffolds for reconstruction of the diaphragm. Handbook of Tissue Engineering Scaffolds: Volume Two. Elsevier.

HEZI-YAMIT, A., SULLIVAN, C., WONG, J., DAVID, L., CHEN, M., CHENG, P., SHUMAKER, D., WILCOX, J. N. \& UDIPI, K. 2009. Impact of polymer hydrophilicity on biocompatibility: implication for DES polymer design. Journal of Biomedical Materials Research Part A: An Official Journal of The Society for Biomaterials, The Japanese Society for Biomaterials, and The Australian Society for Biomaterials and the Korean Society for Biomaterials, 90, 133141.

JONES, J. A., CHANG, D. T., MEYERSON, H., COLTON, E., KWON, I. K., MATSUDA, T. \& ANDERSON, J. M. 2007. Proteomic analysis and quantification of cytokines and chemokines from biomaterial surface-adherent macrophages and foreign body giant cells. Journal of Biomedical Materials Research Part A: An Official Journal of The Society for Biomaterials, The Japanese Society for Biomaterials, and The Australian Society for Biomaterials and the Korean Society for Biomaterials, 83, 585-596.

KAARTHICK, D., SHARMA, A., KUMAR, N., KUMAR, V., GANGWAR, A., MAITI, S., NEGI, M., REMYA, V., MATHEW, D. D. \& DEVARATHNAM, J. 2017. Accelerating full-thickness dermal wound healing using primary mouse embryonic fibroblasts seeded bubaline acellular diaphragm matrix. Trends in Biomaterials and Artificial Organs, 31, 16-23. 
KHARAZIHA, M., FATHI, M. \& EDRIS, H. 2013. Tunable cellular interactions and physical properties of nanofibrous PCL-forsterite: gelatin scaffold through sequential electrospinning. Composites Science and Technology, 87, 182-188.

KUEVDA, E., GUBAREVA, E., GRIGORIEV, T., KRASHENINNIKOV, S., VEREVKIN, A., LUKANINA, K., PUZANOV, D., YEGIYEV, I. K., VASILIEV, A. \& CHVALUN, S. 2019. Application of Recellularized Non-Woven Materials from Collagen-Enriched Polylactide for Creation of Tissue-Engineered Diaphragm Constructs. Современные технологии в медицине, 11.

LANTIS II, J. C., GALLIVAN, E. K., HEKIER, R., CONNOLLY, R., SCHWAITZBERG, S. D. \& CROMBLEHOLME, T. 2000. A comparison of collagen and PTFE patch repair in a rabbit model of congenital diaphragmatic hernia. Journal of Investigative Surgery, 13, 319-325.

LU, L., ZHANG, Q., WOOTTON, D. M., CHIOU, R., LI, D., LU, B., LELKES, P. I. \& ZHOU, J. 2014. Mechanical study of polycaprolactone-hydroxyapatite porous scaffolds created by porogen-based solid freeform fabrication method. Journal of applied biomaterials \& functional materials, 12, 145-154.

MA, Z., HE, W., YONG, T. \& RAMAKRISHNA, S. 2005. Grafting of gelatin on electrospun poly (caprolactone) nanofibers to improve endothelial cell spreading and proliferation and to control cell orientation. Tissue engineering, 11, 1149-1158.

MAGRINA, J. F., GUARDIOLA, T. C., MAGTIBAY III, P. M., KOSIOREK, H. E. \& MAGTIBAY, P. M. 2019. Minimally Invasive Surgery for Resection of Diaphragm Metastases in Ovarian Cancer. Journal of minimally invasive gynecology, 26, 1268-1272.

MANSOURIZADEH, F., ASADI, A., ORYAN, S., NEMATOLLAHZADEH, A., DODEL, M. \& ASGHARIVOSTAKOLAEI, M. 2013. PLLA/HA Nano composite scaffolds for stem cell proliferation and 
differentiation in tissue engineering. Molecular Biology Research Communications, 2, 110.

MASUMOTO, K., NAGATA, K., SOUZAKI, R., UESUGI, T., TAKAHASHI, Y. \& TAGUCHI, T. 2007. Effectiveness of diaphragmatic repair using an abdominal muscle flap in patients with recurrent congenital diaphragmatic hernia. Journal of pediatric surgery, 42.

MCLAUGHLIN, C. J., HANKE, R. E. \& CILLEY, R. E. 2019. Congenital Diaphragmatic Hernia. Clinical Algorithms in General Surgery. Springer.

MERRELL, A. J. \& KARDON, G. 2013. Development of the diaphragm-a skeletal muscle essential for mammalian respiration. The FEBS journal, 280, 4026-4035.

MOHSINA, A., KUMAR, N., SHARMA, A., SHRIVASTAVA, S., MATHEW, D. D., REMYA, V., MAITI, S., SINGH, K. \& SINGH, K. 2017. Polypropylene mesh seeded with fibroblasts: A new approach for the repair of abdominal wall defects in rats. Tissue and Cell, 49, 383-392.

MUNIR, N. \& CALLANAN, A. 2018. Novel phase separated polycaprolactone/collagen scaffolds for cartilage tissue engineering. Biomedical Materials, 13, 051001.

NAVAEI, T., MILAN, P. B., DAVARI, H. R., SAMADIKUCHAKSARAEI, A. \& MOZAFARI, M. 2019. Nanoengineered biomaterials for diaphragm regeneration. Nanoengineered Biomaterials for Regenerative Medicine. Elsevier.

OMURA, A., KANZAKI, R., IKE, A., KANAZAWA, G., KANOU, T., OSE, N., FUNAKI, S., MINAMI, M. \& SHINTANI, Y. 2020. Thoracoscopic diaphragm repair using abdominal insufflation in a patient with hepatic hydrothorax. General Thoracic and Cardiovascular Surgery, 68, $302-$ 305. 
PROTOCOLS ONLINE. 2016. Phosphate buffered saline [Online]. Available: https://www.protocolsonline.com/recipes/phosphate-buffered-saline-pbs/ [Accessed 21 May 2019].

RATHORE, H. S., KUMAR, N., SINGH, K., MAITI, S. K., SHRIVASTAVA, S., SHIVARAMU, S., SAXENA, S. \& AGARWAL, R. K. 2019. Clinical application of acellular matrix derived from the bubaline diaphragm and caprine rumen for the repair of abdominal wall defects in animals. Aceh Journal of Animal Science, 4, 50-60.

RATHORE, H. S., RAghuVANSI, P., GAUTAM, D., MOHAN, D., SINGH, A. K., SINGH, A. P., MAITIAND, S. \& KUMAR, N. 2018. Use of the bubaline acellular diaphragm matrix (ADM) for repair of abdominal wall defects in four different species of animals. International Journal of Chemical Studies, 6, 157-161.

RATNER, B. D. 2015. Chapter 3 - The Biocompatibility of Implant Materials. In: BADYLAK, S. F. (ed.) Host Response to Biomaterials. Oxford: Academic Press.

SMITH, M., PARAN, T., QUINN, F. \& CORBALLY, M. 2004. The SIS extracellular matrix scaffoldpreliminary results of use in congenital diaphragmatic hernia $(\mathrm{CDH})$ repair. Pediatric surgery international, 20, 859-862.

STALDER, A. F., KULIK, G., SAGE, D., BARBIERI, L. \& HOFFMANN, P. 2006. A snake-based approach to accurate determination of both contact points and contact angles. Colloids and surfaces A: physicochemical and engineering aspects, 286, 92-103.

STALDER, A. F., MELCHIOR, T., MÜLLER, M., SAGE, D., BLU, T. \& UNSER, M. 2010. Low-bond axisymmetric drop shape analysis for surface tension and contact angle measurements of 
sessile drops. Colloids and Surfaces A: Physicochemical and Engineering Aspects, 364, $72-$ 81.

SUZUKI, K., KOMURA, M., TERAWAKI, K., KODAKA, T., GOHARA, T., KOMURA, H. \& NAKAYAMA, Y. 2018. Engineering and repair of diaphragm using biosheet (a collagenous connective tissue membrane) in rabbits. Journal of pediatric surgery, 53, 330-334.

TANG, L. \& HU, W. 2005. Molecular determinants of biocompatibility. Expert review of medical devices, 2, 493-500.

UNIVERSITY OF CALIFORNIA SAN FRANCISCO. 2018. Congenital Diaphragmatic Hernia [Online]. Available: $\quad$ https://surgery.ucsf.edu/conditions--procedures/congenital-diaphragmatichernia.aspx [Accessed 19 May 2019].

URITA, Y., KOMURO, H., CHEN, G., SHINYA, M., SAIHARA, R. \& KANEKO, M. 2008. Evaluation of diaphragmatic hernia repair using PLGA mesh-collagen sponge hybrid scaffold: An experimental study in a rat model. Pediatric Surgery International, 24, 1041-1045.

VILLARREAL-GÓMEZ, L. J., VERA-GRAZIANO, R., VEGA-RÍOS, M. R., PINEDA-CAMACHO, J. L., ALMANZA-REYES, H., MIER-MALDONADO, P. A. \& CORNEJO-BRAVO, J. M. 2014. Biocompatibility evaluation of electrospun scaffolds of poly (L-Lactide) with pure and grafted hydroxyapatite. Journal of the Mexican Chemical Society, 58, 435-443.

ZHAO, W., JU, Y. M., CHRIST, G., ATALA, A., YOO, J. J. \& LEE, S. J. 2013. Diaphragmatic muscle reconstruction with an aligned electrospun poly ( $\varepsilon$-caprolactone)/collagen hybrid scaffold. Biomaterials, 34, 8235-8240. 
Tables:

Table 1. PCL and Gelatin percentage in each sample

\begin{tabular}{ccc}
\hline Label & \%PCL & \% Gelatin \\
\hline $\mathrm{PLC}$ & 100 & 0 \\
\hline $\mathrm{PCL} / 1 \mathrm{G}$ & 90 & 10 \\
\hline $\mathrm{PCL} / 2 \mathrm{G}$ & 80 & 20 \\
\hline $\mathrm{PCL} / 3 \mathrm{G}$ & 70 & 30 \\
\hline $\mathrm{PCL} / 4 \mathrm{G}$ & 60 & 40 \\
\hline
\end{tabular}

Table 2. Qualitative evaluation of the inflammatory response in tissue

\begin{tabular}{ccc}
\hline Level & Immune response & Observations \\
\hline 1 & Lack of response & Normal tissue \\
\hline 2 & Smooth & Macrophage and plasma cells \\
\hline 3 & Moderate & Macrophage, plasma cells, Neutrophils, and Lymphocyte capsules \\
\hline 4 & Severe & Necrosis \\
\hline
\end{tabular}


Figures:

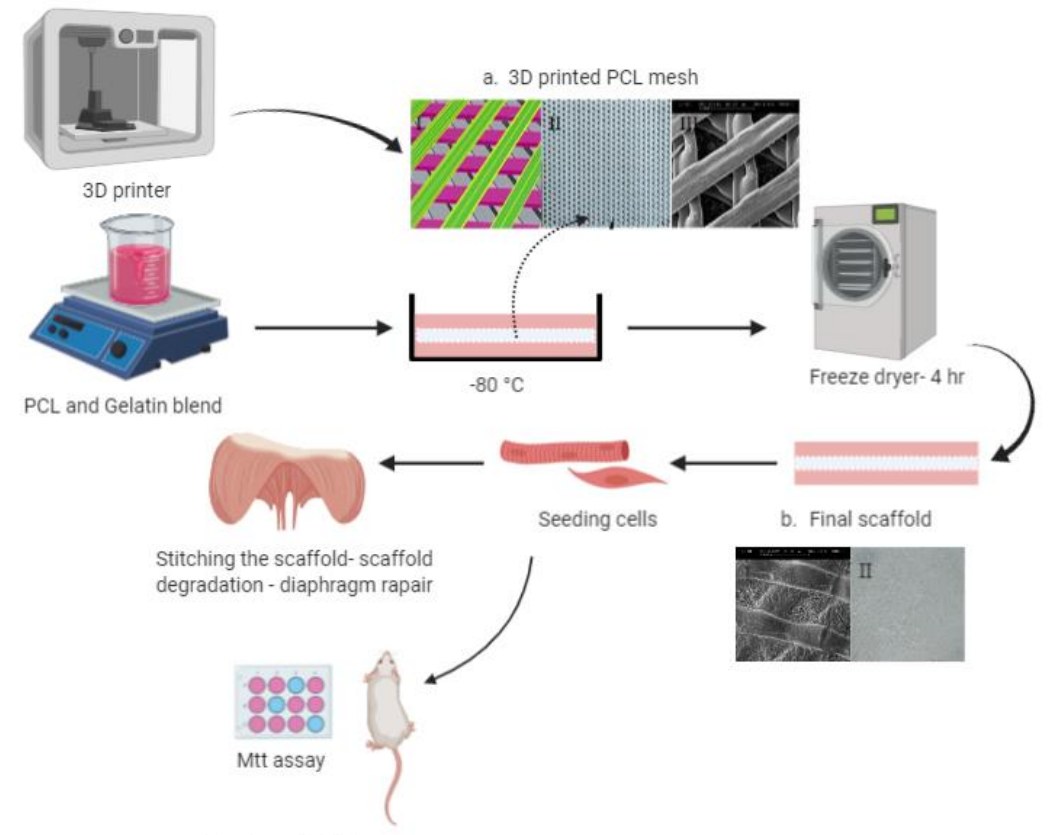

In vivo and in vitro assays

Figure 1. Schematic of the fabrication process and treatment strategy. a: PCL mesh ( $60 \mu \mathrm{m}$ wide struts with $45^{\circ}$ angle in 3 layers) (I) 3D model in 3D builder (II) 3D printed mesh (III) SEM image, b: (I) SEM image of scaffold, (II) final scaffold. 

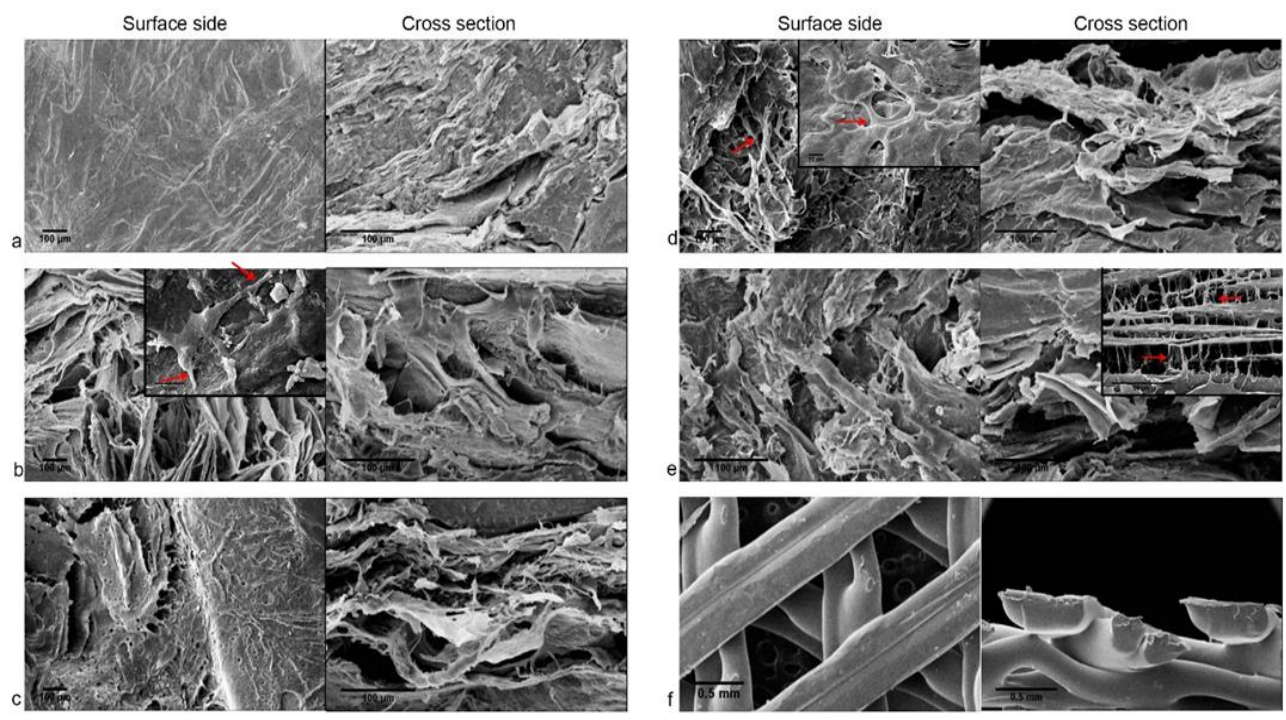

Figure 2. SEM images. Scaffold surfaces and cross sections. Red arrows point at fibroblast filopodia and lamellipodia showing cell adhesion (a) PCL (b) PC:/1G (c) PCL/2G (d) PCL/3G (e) $\mathrm{PCL} / 4 \mathrm{G}(\mathrm{f}) \mathrm{PCL}$ 3D-printed mesh. 


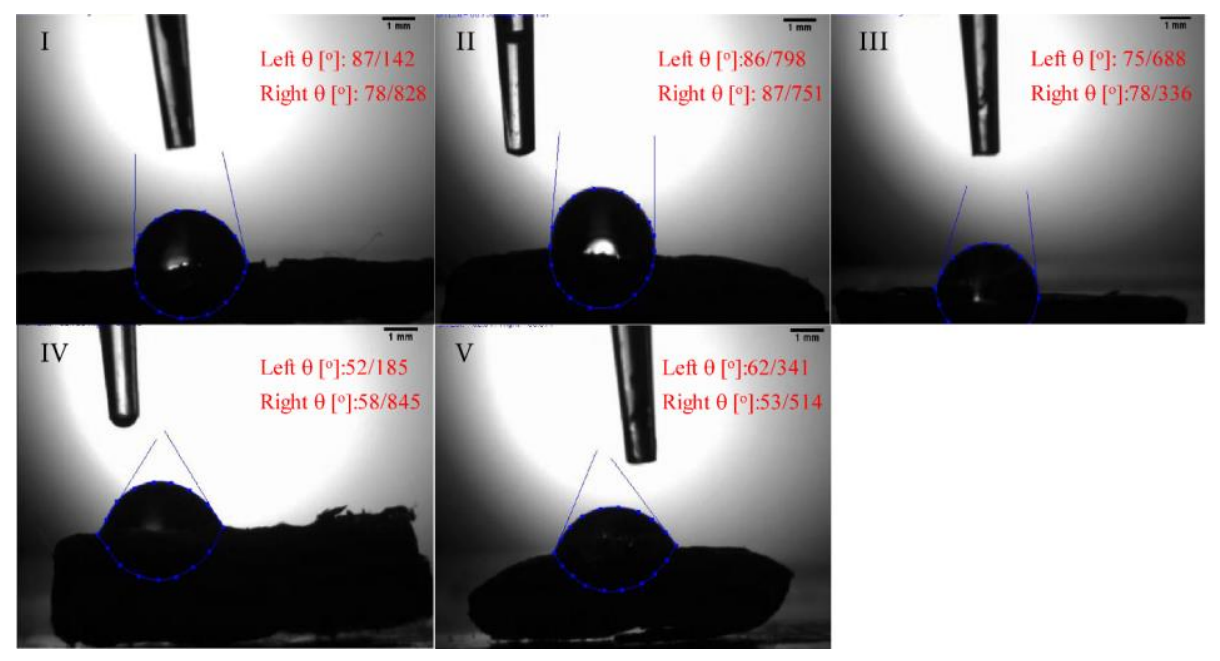

Figure 3. Drop shape analysis of surface tension and contact angle measurements, $\mathrm{T}: 25^{\circ} \mathrm{C}$, the contact angle of water drops. 
A

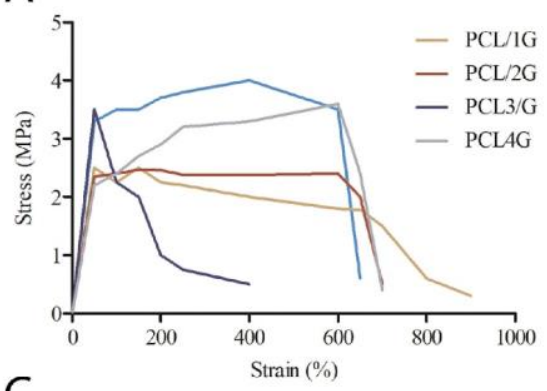

C

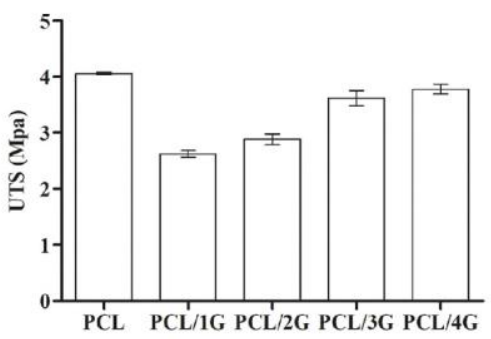

B

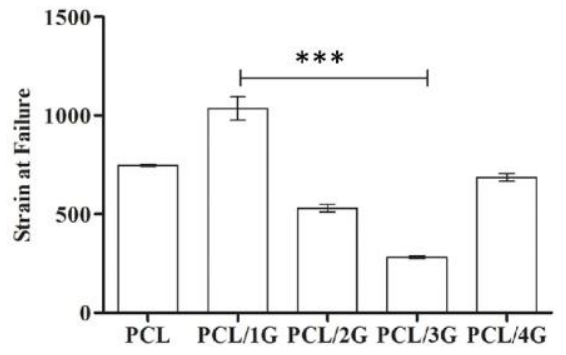

D

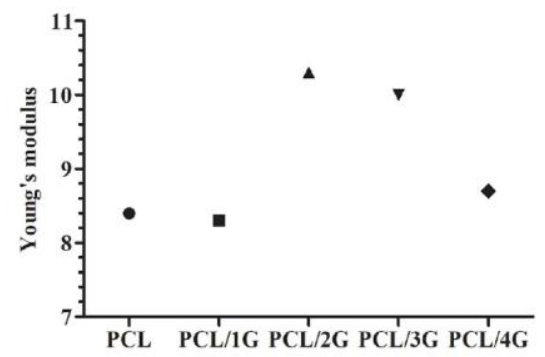

Figure 4. Comparison of for the mechanical properties of the five samples. A) Stress-strain curves. B) Ultimate percentage of strain at failure. C) ultimate tensile strength (UTS). D) Young's modulus.xxx 


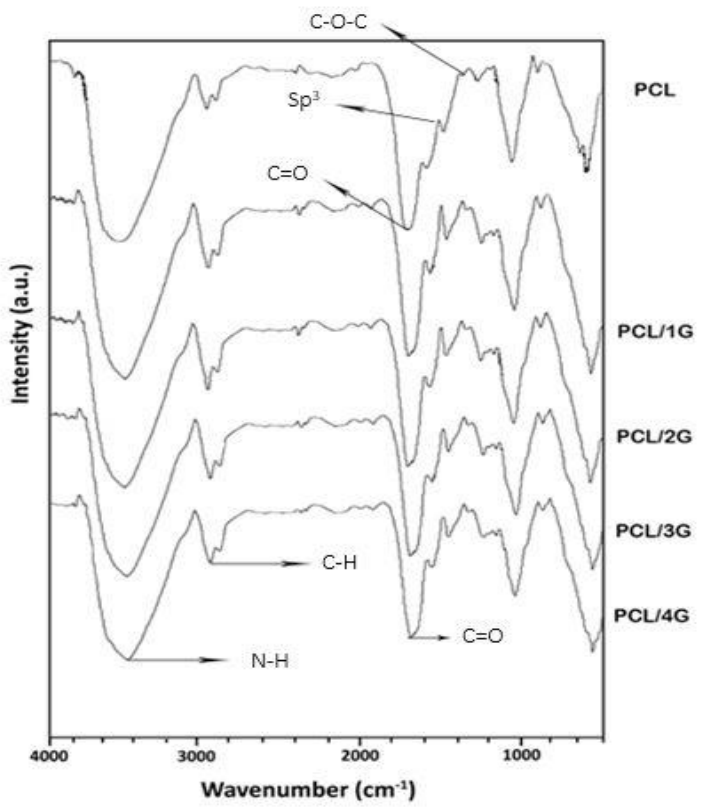

Figure 5. FTIR analysis of the prepared scaffolds. $x x x$ 


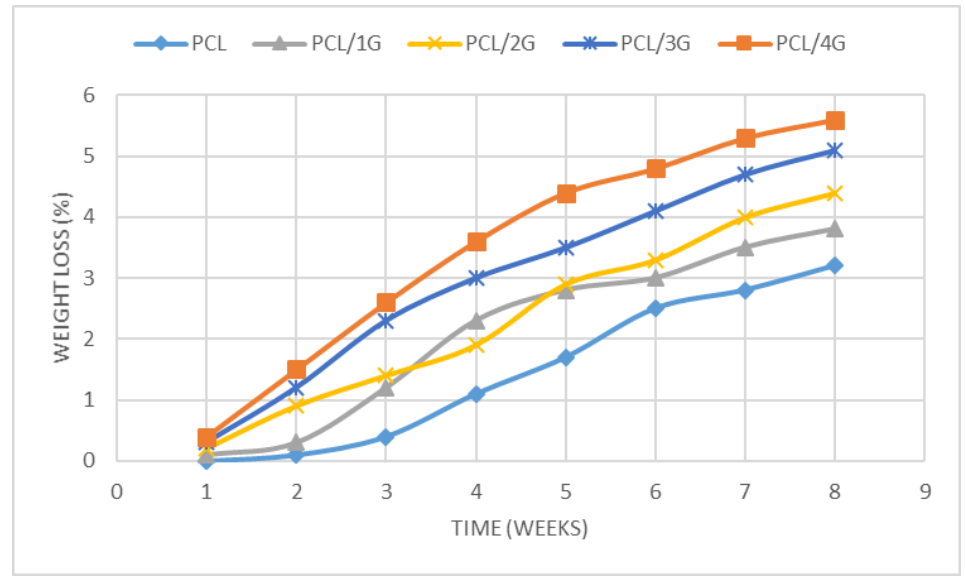

Figure 6. Percentage weight loss of samples over 8 weeks in PBS solution. $x x x$

Commented [HJ4]: Error bars? 

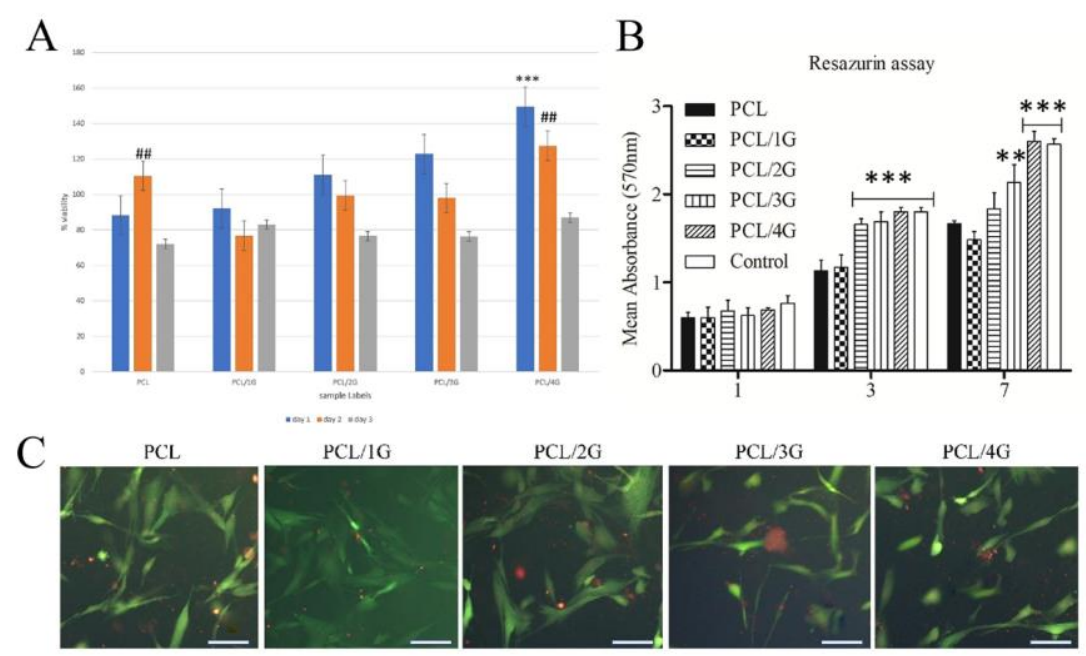

Figure 7. In vitro studies. A) MTT assay test to assess cell viability. A non-parametric Kruskal-Wallis test was used to determine statistical significances (\#\#p<0.01, $* * * p<0.001$, and $* * * * p<0.0001$ ). Data are shown as mean values \pm standard deviation (SD). B) Resazurin assay for evaluation of 3T3 fibroblast cells survival/proliferation within the scaffolds after 1,3 and 7 days of cell seeding ( ${ }^{* *} p$ $\left.<0.01,{ }^{* * *} p<0.001\right)$. C) Confocal microscopic images of each group. Higher numbers of viable cells were detected (green dye) for each group showing the cytocompatibility of scaffolds. 

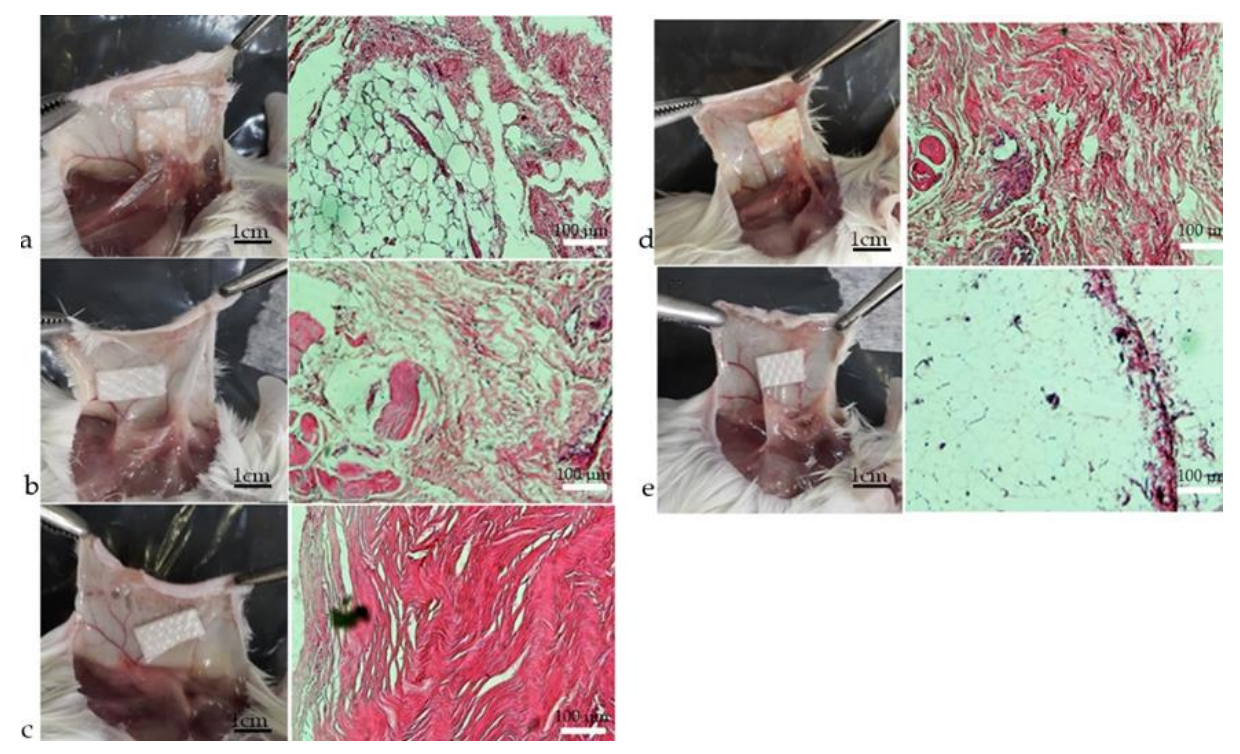

Figure 8. Macroscopic and histologic images of surrounded fibrotic tissue of the implanted scaffolds in: a) PCL, control sample; b) PCL/1G; c) PCL/2G; d) PCL/3G; e) PCL/4G. Macroscopic scale bars represent $1 \mathrm{~cm}$; histologic scale bars represent $100 \mu \mathrm{m}$. 
